\title{
INCORPORATING THE PUBLIC INTEREST IN PUBLIC-PRIVATE PARTNERSHIPS IN ONTARIO: A CASE STUDY OF THE EGLINTON CROSSTOWN
}

\author{
By \\ Joseph Tohill \\ B.A., University of British Columbia, 2011 \\ A Major Research Paper \\ Presented to Ryerson University \\ In partial fulfillment of the requirements for the degree of \\ Master of Planning \\ In \\ Urban Development
}

Toronto, Ontario, Canada, 2016

(C) Joseph Tohill, 2016 


\section{Author's Declaration}

I hereby declare that I am the sole author of this MRP. This is a true copy of the MRP, including any required final revisions.

I authorize Ryerson University to lend this MRP to other institutions or individuals for the purpose of scholarly research

I further authorize Ryerson University to reproduce this MRP by photocopying or by other means, in total or in part, at the request of other institutions or individuals for the purpose of scholarly research.

I understand that my MRP may be made electronically available to the public. 


\title{
INCORPORATING THE PUBLIC INTEREST IN PUBLIC-PRIVATE PARTNERSHIPS IN ONTARIO: A CASE STUDY OF THE EGLINTON CROSSTOWN
}

\author{
(C) Joseph Tohill, 2016 \\ Master of Planning \\ In \\ Urban Development \\ Ryerson University
}

\begin{abstract}
Although the Province of Ontario sees Public-Private Partnerships (P3s) as an effective means to procure major transportation infrastructure, the public interest implications of P3s from a planning perspective are little understood. P3s are purported to deliver costsavings to the public sector through transferring expanded elements of risk to the private sector. However, critics argue that P3s erode the public interest through reduced project transparency, weakened public participation, and higher life-cycle project costs. Through a case study of the Eglinton Crosstown transit line in Toronto, this paper evaluates the extent to which the public sector agency, Infastructure Ontario (IO), has been able to fulfill a series of evaluative criteria grounded in the public interest. Although IO has been able to maintain the public interest in the case of the Eglinton Crosstown, a lack of consistency in project transparency and weakened ex post reporting standards hampers the ability of the agency to consistently uphold the public interest in present and future projects.
\end{abstract}

Keywords:

Public-private partnerships, Infrastructure Ontario, Eglinton Crosstown, transportation planning, public interest 


\section{Acknowledgements}

I would first like to acknowledge the guidance and support from my supervisor, Dr. Matthias Sweet. His insight has been helpful throughout every stage of the process, from my initial musings on the topic of P3s, to the final polish right at the end. In addition, I would like to thank my second reader Professor David Amborski for his additional comments and feedback on how to make my paper better. Their guidance has undoubtedly pushed me to make my arguments stronger and my writing better.

To my fellow colleagues and friends here at Ryerson, thank-you so much for your support and comradery over the past 18 months. You have all been a source of inspiration and instilled in me a sense of optimism in what can be accomplished through hard work and dedication. And to all my friends, near and far, thank you for the support, good memories, and words of encouragement.

And finally, thank you to my family and friends back in Vancouver who have been an invaluable source of support and encouragement. To my parents and sisters, who have always pushed me to follow my dreams (even if it means flying halfway across the country for planning school) and for being there for me whenever I needed it, thank you. Without your love and support, none of this would have been possible. 


\section{Table of Contents}

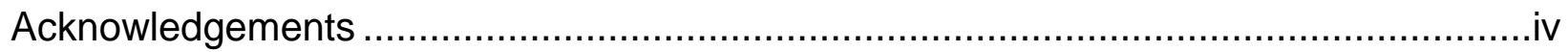

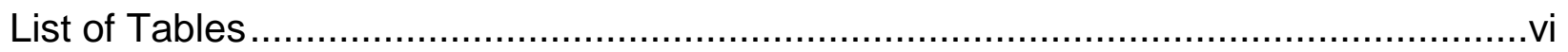

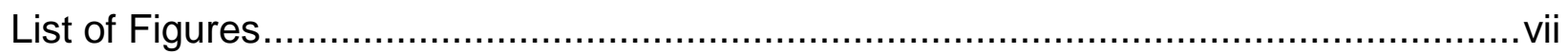

List of Acronyms .................................................................................................

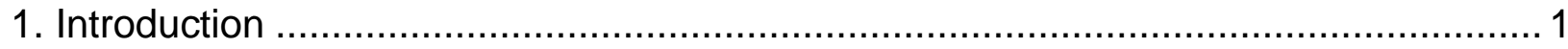

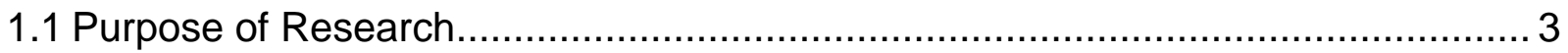

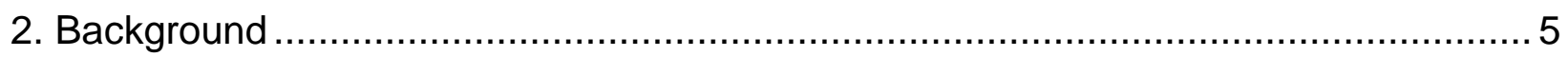

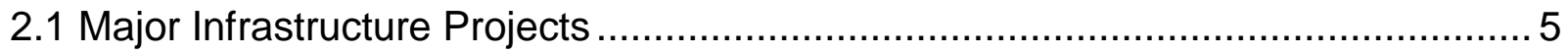

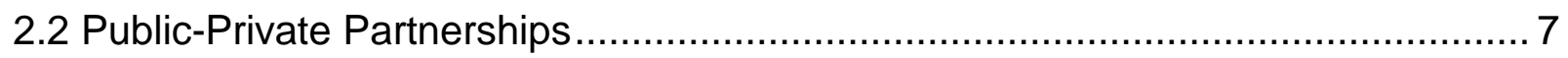

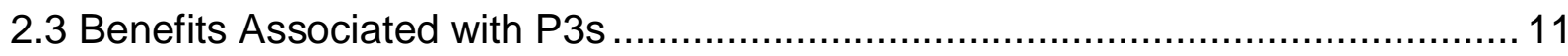

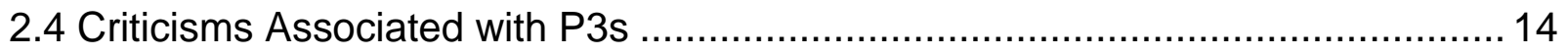

2.5 Developing Evaluative Criteria for P3s ...................................................... 18

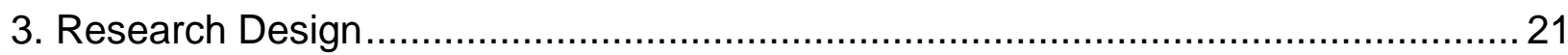

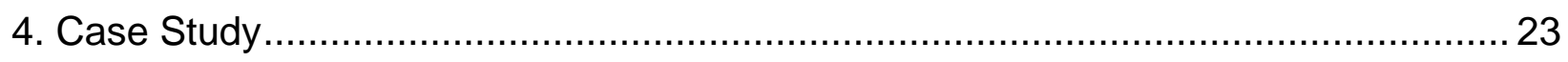

4.1 Public-Private Partnerships in Ontario and Infrastructure Ontario.......................23

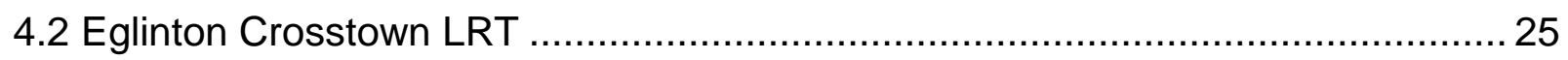

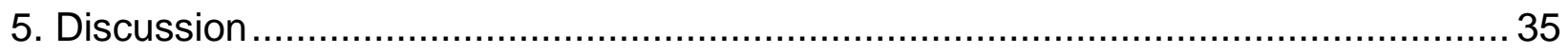

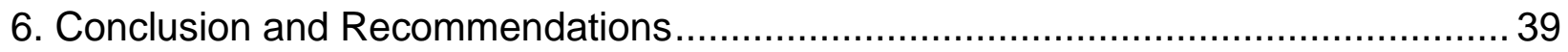

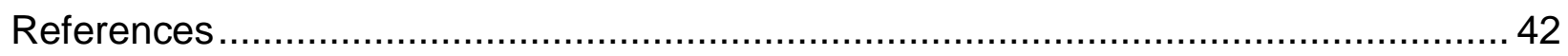




\section{List of Tables}

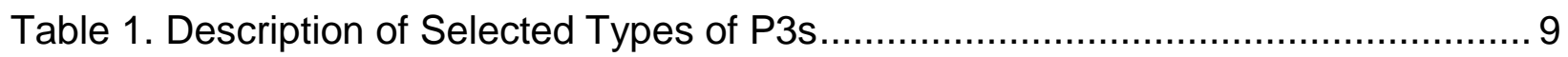

Table 2. Public Consultation Events for the Eglinton Crosstown, 2008-2010 ................ 30 


\section{List of Figures}

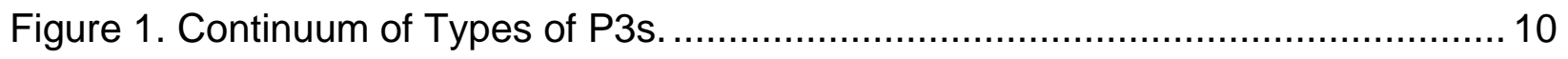

Figure 2. Components of a Value for Money Calculation. ............................................ 14

Figure 3. The Eglinton Crosstown LRT Route....................................................... 25

Figure 4. Value for Money Calculation for Eglinton Crosstown. ..................................2 29 


\section{List of Acronyms}

$\begin{array}{ll}\text { AFP } & \text { Alternative Financing and Procurement } \\ \text { BOT } & \text { Build-Operate-Transfer } \\ \text { DBFM } & \text { Design-Build-Finance-Maintain } \\ \text { DBFOM } & \text { Design-Build-Finance-Operate-Maintain } \\ \text { ETR } & \text { Express Toll Route } \\ \text { GTHA } & \text { Greater Toronto and Hamilton Area } \\ \text { IO } & \text { Infrastructure Ontario } \\ \text { LRT } & \text { Light-rail Transit } \\ \text { P3 } & \text { Public-Private Partnership } \\ \text { PSC } & \text { Public Sector Comparator } \\ \text { TTC } & \text { Toronto Transit Commission } \\ \text { VfM } & \text { Value-for-money }\end{array}$




\section{Introduction}

The addition of 3 million new inhabitants to the Greater Toronto Area by 2041 will undoubtedly put enormous pressure on the region's transportation system (Province of Ontario, 2014a). And with the province planning to invest more than $\$ 130$ billion in public infrastructure over the next 10 years, questions over how best to finance major transportation projects has become an issue of growing concern (Province of Ontario, 2014b). Although major transportation infrastructure projects have traditionally been designed, built, financed, and maintained by the public sector, policymakers have increasingly turned to the private sector to take-on some of the risk and financing associated with the implementation of major infrastructure projects. Also referred to as Public-Private-Partnerships (P3s) these arrangements are defined as "a cooperative venture between the public and private sectors, built on the expertise of each partner that best meets clearly defined public needs through the appropriate allocation of resources, risks, and rewards" (The Canadian Council for Public Private Partnerships).

Premised on the assertion that P3s tap into the private sector's propensity for efficiency, risk minimization, and project management expertise, governments around the world have been increasingly partnering with the private sector to deliver major infrastructure project on-time and within budget. In Ontario, the allure of using P3s to help address infrastructure shortages has led the province to create a special purpose government agency, Infrastructure Ontario (IO), to manage the construction and financing of public works through the P3 model. Furthermore, IO has mandated that all provincially funded infrastructure projects greater than $\$ 100$ million must consider the use of P3s through the Alternative Financing and Procurement (AFP) model. 
However, the intrusion of private interests in the provision of public infrastructure has been met with considerable consternation from academics, practitioners, and the general public. Critics charge that the private sector's motivation for profit will necessarily circumvent the democratic process and sequester every legal means for extracting as much revenue from projects as possible (Krawchenko and Stoney, 2011). And if Ontario's experience with the Highway 407 express toll route (ETR) is any indication, an ill-conceived P3 contract could constrict the government's ability to reignin skyrocketing toll rates in the future and result in escalating legal fees when attempting to take on the private consortium through the court system (Vining and Boardman, 2008a). Furthermore, the Auditor General's assertion that the AFP model has cost the province an additional $\$ 8$ billion when compared to the traditional procurement process for infrastructure projects casts doubt on the ability of P3s to save the government money in the long run (Office of the Auditor General of Ontario, 2014).

Do the significant concerns associated with P3s overshadow their supposed benefits? Are P3s a worthy pursuit for the Provincial Government? The results from past research into P3 projects is inconclusive as to whether greater private sector involvement in infrastructure has been positive or negative. Indeed, case studies from around the world have shown P3s that have been successful in cost-effectively delivering high-quality infrastructure on-time and P3 that have been failures due to costly legal battles and poor integration with existing infrastructure (National Audit Office, 2011; Vining and Boardman, 2008a) In reality, the success of a P3 is likely more a function of its structure and planning context than whether it was implemented through a P3 as such. Consequently, determining which factors lead to a successful P3 project 
is a crucial endeavour in a climate progressively defined by increasing private sector involvement in the provision of major transportation infrastructure. In particular, outlining the factors associated with successful P3 projects will provide a mechanism with which to plan and evaluate future infrastructure projects so that their conduciveness to the P3 model can be determined and the public interest may be maintained.

\subsection{Purpose of Research}

As professionals particularly concerned with upholding the public interest, planners have an especially important role to play in applying public interest concerns to the planning and evaluation of P3s in major infrastructure projects. Although defining the public interest remains an elusive concept in planning theory (Grant, 2006; Campbell, 2012), when it comes to planning major infrastructure projects, planners should generally strive to enhance the overall infrastructure network, solicit engagement from the public, minimize the cost for taxpayers, and maintain government flexibility in making future infrastructure plans (Ortiz and Buxbaum, 2008; Siemiatycki and Farooqi, 2012). While it is not yet clear whether P3s deliver financial savings to the public after accounting for a project's entire lifecycle, the province's predisposition to P3s through the AFP model means planners must be well-equipped to evaluate whether individual P3s uphold the public interest. Consequently, the development of an evaluative criteria grounded in the public interest is crucial for planners looking to maximize the effectiveness of the P3 model in future transportation projects.

The purpose of this research is to answer the following question: 
- To what extent do transportation infrastructure projects developed through the P3 model in Ontario uphold the public interest through fulfilling success criteria grounded in a planning perspective?

Through answering this question it is hoped that planners will be better-equipped to evaluate the effectiveness of transportation projects based on a predetermined set of criteria, while also offering empirically-grounded recommendations on how future transportation projects may be optimized to better support the public interest. 


\section{Background}

\subsection{Major Infrastructure Projects}

Evaluating and measuring the success of infrastructure projects has been the subject of considerable scrutiny in planning and project management literature. Although infrastructure investments are often made with the objective of attaining tangible benefits for the public such as providing increased access to transit options, improving road safety conditions for cyclists, or increasing the capacity of the sewage system, the literature is decidedly mixed on whether there is a causal link between investments in public infrastructure and economic growth (Sanchez-Robles, 1998; Rietveld, 1989; Infrastructure Canada, 2007). As economic considerations are often a crucial component in establishing the public interest argument for a particular project, planners need to be acutely aware of how they are defining types of infrastructure projects so that they may properly understand the economic implications of a particular project and its subsequent public interest considerations. When looking at major infrastructure projects or "mega-projects" in particular, it is important to note the defining characteristics and unique risks that these projects have historically embodied so that an effective evaluative framework can be developed.

An analysis of the characteristics and risks associated with megaprojects reveals a history rife with high degrees of project complexity, considerable public mismanagement, ballooning cost escalations, and lengthy project delays. In reviewing the policy and planning considerations associated with large infrastructure projects, Flyvbjerg (2007, p. 579) distills several key characteristics: 
- Such projects are inherently risky due to long planning horizons and complex interfaces.

- Technology is often not standard.

- Decision making and planning are often multi-actor processes with conflicting interests.

- Often the project scope or ambition level will change significantly over time.

- Statistical evidence shows that such unplanned events are often unaccounted for, leaving budget contingencies sorely inadequate

- As a consequence, misinformation about costs, benefits, and risks is the norm.

- The result is cost overruns and/or benefit shortfalls with a majority of projects.

With such a high degree of complexity and expense, megaprojects present a number of key challenges in ensuring that the public interest is adequately maintained through effective project planning. In particular, Flyvbjerg, Bruzelius, and Rothengatter (2003) note that the government is tasked with a range of roles in a conventional, publicallymanaged project such as establishing the choice of technology, planning the method of implementation, fulfilling operations, and pursuing financing. However, they argue that "the government [cannot] act effectively as both promoter of a project and the guardian of public interest issues such as protection of the environment, safety, and of the taxpayer against unnecessary financial risks" (p. 90). The implication of performing competing roles in the development of major infrastructure is that the government fails to maintain the public interest as is evident in the considerable cost overruns and mismanagement associated with past megaprojects. 
History overwhelming suggests that despite the utilization of considerable planning and economic forecasting expertise, megaprojects are rarely on-time and within the specified budget. In a study of 258 major transportation infrastructure projects, Flyvbjerg, Holm, and Buhl (2002) reveal that costs are underestimated in almost 9 out of 10 projects, with actual costs on average $28 \%$ higher than estimated costs. These cost underestimations are most prominent in rail infrastructure, where the average cost escalation for 58 projects was $44.7 \%$. While it may be tempting to claim that cost underestimation is a result of technical errors or "honest" mistakes, evidence suggests otherwise. After reviewing several case studies, Flyvbjerg (2007) argues that strategic misrepresentation and/or political pressure are the main culprits for cost underestimation. In many cases, project promoters will emphasize the benefits and downplay the risks and costs associated with projects in order to more easily receive project approval and funding. The perilous implication of this is that the government ends up directing huge amounts of funding towards poorly planned and ill-managed projects that end up costing tax payers' money and thus inadequately maintain the public interest.

\subsection{Public-Private Partnerships}

Throughout much of the $20^{\text {th }}$ century, major infrastructure projects have typically been built, financed, maintained, and operated by the public sector. In the traditional approach to a major infrastructure project, the public agency would prepare the project, contract out construction, and contract out maintenance and operations separately if government was not taking care of these aspects themselves (Koppenjan, 2008). Thus the role of the private sector was significantly constrained to executing various design or 
construction aspects of a project as specified by the government. De Bettignies and Ross (2003, p. 137) note that the process by which a project is developed can typically be broken down into 4 main tasks:

Task 1: defining and design the project

Task 2: financing the capital costs of the project

Task 3: building the physical assets (e.g. road, school, etc.), and

Task 4: operating and maintaining the assets in order to deliver the product/service.

In a traditional project the government would normally carry out Tasks 1,2 and 4, while typically leaving the actual construction of physical assets to the private sector. Therefore, while the private sector has occasionally played a role in the construction and operation of particular aspects of transportation systems, the public sector has overwhelming maintained control over the financing of infrastructure investments and project management.

However, over the past 20 years, due to the perceived economic efficiencies, risk mitigation strategies, and technological innovations engendered by the private sector, policy-makers have increasingly sought the expertise of private actors through PublicPrivate Partnerships (P3s) to achieve a public-private collaboration on the provision of major transportation projects. Although the complexities of P3s and their diverse characteristics make them difficult to define, Kawk, Chih, and Ibbs (2009: 52) describe them as "a cooperative arrangement between the public and private sectors that involves the sharing of resources, risks, responsibilities, and rewards with others for the achievement of joint objectives." While this broad definition reveals the overarching 
collaborative relationship between the public and private sectors, it is important to note that P3s can take a variety of different forms, from Operation-Maintenance, to BuildOwn-Operate (See Table 1).

\begin{tabular}{|c|c|}
\hline Types of PPP & Descriptions \\
\hline $\begin{array}{l}\text { Operation-Maintenance } \\
(\mathrm{OM})^{2}\end{array}$ & $\begin{array}{l}\text { - The private sector is responsible for all aspects of operation and maintenance. } \\
\text { - Although the private sector may not take the responsibility of financing, it may } \\
\text { manage a capital investment fund and determine how the fund should be used } \\
\text { together with the public sector. }\end{array}$ \\
\hline $\begin{array}{l}\text { Design-Build-Operate } \\
(\mathrm{DBO})^{\mathrm{b}}\end{array}$ & $\begin{array}{l}\text { The private sector is responsible for the design, construction, operation, and } \\
\text { maintenance of a project for a specified period prior to handling it over to the } \\
\text { public sector. }\end{array}$ \\
\hline $\begin{array}{l}\text { Design-Build-Finance- } \\
\text { Operate }(\mathrm{DBFO})^{c}\end{array}$ & $\begin{array}{l}\text { - The private sector is responsible for the finance, design, construction, operation, } \\
\text { and maintenance of a project. } \\
\text { - In nearly all cases, the public sector retains full ownership over the project. }\end{array}$ \\
\hline $\begin{array}{l}\text { Build-Operate-Transfer } \\
\text { (BOT) }^{d}\end{array}$ & $\begin{array}{l}\text { - The private sector is responsible for the finance, design, construction, operation, } \\
\text { and maintenance of a project for a concession period. } \\
\text { - The asset is transferred back to the government at the end of concession period, } \\
\text { often at no cost. }\end{array}$ \\
\hline $\begin{array}{l}\text { Build-Own-Operate } \\
(\mathrm{BOO})^{\mathrm{e}}\end{array}$ & $\begin{array}{l}\text { - Similar to a BOOT project, but the private sector retains the ownerships of the } \\
\text { asset in perpetuity. } \\
\text { - The government only agrees to purchase the services produced for a fixed length } \\
\text { of time. }\end{array}$ \\
\hline
\end{tabular}

a The Wordd Bank, Public-Private Partnership Units Lessons for their Design and Use in Infrastructure, Washington DC., 2007.

b. E.S. Kely, S. Haskins, and P.D. Reiter, "Implementing a DBO Project," Joumal of American Woter Works Associadion, 90/6 (une 1998): 34-46

c. US. Department of Transportation, "PPP Options," Federal Highway Administration (PHWA). <wwwifhwadotgow/PPP/dblahtm>.

d. MM. Kumaraswamy and X.Q. Zhang "Governmental Role in BOT-led Infrastructure Development," Intemationd joumal of Project Management, $19 / 4$ (May 2001): 195-205.

e. L.W. Chege and P.D. Riwelamia, "Private financing of Construction Projects and Procurement Systems: An Integrated Approach," in Proceedings of $O B$ World Building Congress, Wellington, New Zealand, April 2001.

Table 1. Description of Selected Types of P3s. Source: Kwak, Chih, and Ibbs (2009, p. 54)

In addition, Figure 1 shows how each of the types of P3s are best arranged along a continuum, with the P3 types featured on the right of the continuum embodying a greater degree of private sector involvement and types on the left embodying a greater degree of public sector involvement. Grimsey and Lewis (2005) offer even more specific criteria as to what constitutes a P3. In particular, they highlight how it is important to 
acknowledge that a P3 is neither full privatization nor simply a one-time engagement with a private contractor. Rather, with a P3 the emphasis is on:

long-term contracts and strict performance regimes, such as build-operatetransfer (BOT) or design-build-finance-operate (DBFO) projects to design, construct, finance, manage, and operate infrastructure under a concession, with revenues (either from government or users) according to services supplied ( $p$. 346).

Consequently defining a project as a $\mathrm{P} 3$ requires a qualitative evaluation as to the extent to which a future-oriented and collaborative approach to infrastructure provision is achieved.

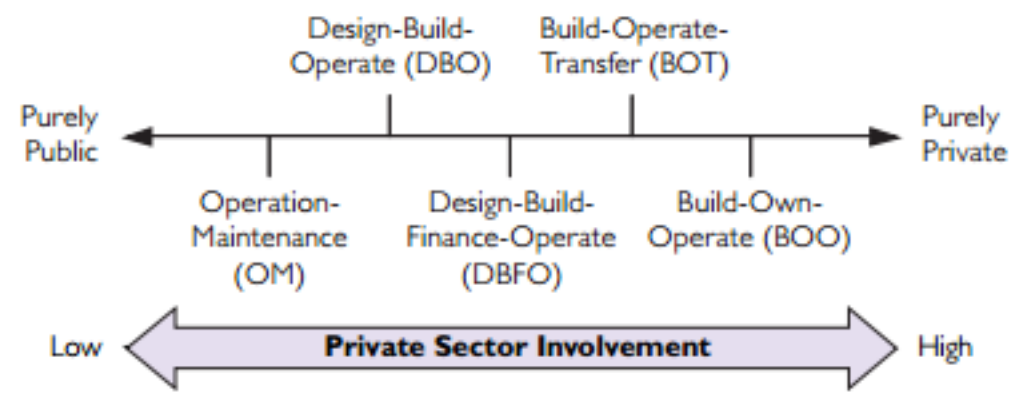

Figure 1. Continuum of Types of P3s. Source: Kwak, Chih, and Ibbs (2009, p. 54)

Despite the multifarious forms that P3s take depending on the actors involved and their unique local contexts, there are several common elements that characterize most P3s. In reviewing the common economic characteristics associated with the current wave of P3s, De Bettignies and Ross (2003) derive three key elements:

1. They are an extension of contracting-out to a larger number tasks

2. They bundle multiple responsibilities to a unique consortium of partners, and 
3. They allocate the financing component of a project to the private partner. Therefore, the public sector takes a considerably smaller role in the management and financing of projects, and instead relies on the expertise of the private consortium to implement a greater number of the tasks involved. Consequently, the public sector will typically provide project requirements in the form of output specifications, which the private sector will then meet through developing its own approach to designing, financing, building, and operating the project (Yescombe, 2007). Payments will then ordinarily be made to the private partner for the duration of the project either by the government directly or the users. Any shortcomings on the part of the private agency in meeting the predetermined output specifications are met with deductions in payment.

\subsection{Benefits Associated with P3s}

It is purported that by bundling multiple tasks under one contract and allocating financing responsibilities to a private agency, the public sector is able to tap into a number of project benefits that it would not acquire when pursuing the traditional model of infrastructure provision. Perhaps the biggest benefit the government is claimed to receive is the re-allocation of project risk away from the public sector. By bundling multiple project components such as the design, construction, operations, and maintenance of a major infrastructure project under one concession, the public sector is effectively transferring the risk associated with cost overruns and project delays to the private agency. In a detailed review of potential risks facing an infrastructure project, Grimsey and Lewis (2002) highlight at least nine types of risk from technical risk due to engineering and design failures to environmental risks from adverse environmental impacts and hazards. The authors contend that a successful infrastructure project 
design requires an expert analysis of each type of risk and the design of contractual arrangements that allocate the burden or risk appropriately between the relevant parties. While a traditional infrastructure project would place almost all of the risk with the public sector, P3s allow for the reallocation of a greater share of the nine types of risk with the private sector.

A further benefit associated with P3s is that their structure allows for a more streamlined project management process and an opportunity to better harness the creativity and expertise of the private sector in the provision of infrastructure. By bundling operation and construction within one contract, the government creates incentives for the private sector to reduce costs over the lifespan of a project while also enhancing the private actor's ability to properly coordinate each of a project's components (International Transport Forum, 2013). In particular, when the private actor is forced to consider how decisions made early in the project may influence operations later on, they are encouraged to take a more holistic approach to project management that may cut costs over the lifecycle of a project and establish greater efficiency. These points are perhaps best elucidated by De Bettignies and Ross (2003) who show that separating construction and operations may be reduce incentives to achieve lifecycle efficiencies for a project. For example, a construction firm tasked exclusively with building a facility has an incentive to deliver the construction component of a project at a lower cost, and so may not invest in more durable or expensive construction materials. Therefore, when it comes to operations, a facility may require greater expenditures in upkeep and maintenance over time, thus reversing any savings gained in the construction phase of a project. Conversely, tasking one agency with both design, 
construction, and operations incentivizes savings over the lifetime of a project since the company will be able to see how investments made in better design and construction materials will eventually pay-off in enhanced operations later on. Therefore, the structure of P3s is often conducive to a more holistic approach to project management which thus allows for enhanced financial savings for an infrastructure project over time.

Proponents of P3s often use these enhanced life-cycle savings arguments to contend that projects delivered through a P3 present considerable savings to the public sector compared to the traditional infrastructure delivery model after factoring in risk. The difference in cost between a P3 project and a traditional project is often referred to as "Value for Money", wherein the government is able to achieve a higher "value" from its overall cost expenditures when delivering a project using a P3 than a traditional model. In a comprehensive analysis of the "state of practice" in VfM analyses, Morallos and Amekudzi arrive at the following definition based on the U.K.'s Her Majesty's (HM, 2006 Treasury Value for Money Assessment Guide:

Value for money is defined as the optimum combination of whole-of-life costs and quality (or fitness for purpose) of the good or service to meet the user's requirement. The term whole-of-life is used to refer to the lifecycle of the good or service based on the lowest cost bid. (p. 7).

The VfM calculation is therefore predicated on comparing all the costs and risks associated with using a P3 for a particular transportation project with the costs and risks associated with using a traditional procurement approach (also referred to as the public sector comparator or PSC). More specifically, VfM is defined as "a measure of the extent to which costs would be saved when delivering a public infrastructure project 
through a P3 relative to a traditional government-led procurement approach" (Siemiatycki and Faroogi, 2012: 287). When comparing the P3 with the Traditional Procurement approach, the public agency would typically first outline the base costs (which may include design and construction), the transaction costs, and the retained risk associated with the PSC for a project, and compare each of those components to the proposal of the P3 under consideration (Grimsey and Lewis, 2005). If the difference between the P3 and the PSC indicates a financial savings to the public sector, this savings is referred to as "value for money". As Figure 2 indicates, the ability of the private sector to reduce the retained risk due to economic efficiency and a profitoriented operational model is what often creates VfM in PPP projects.

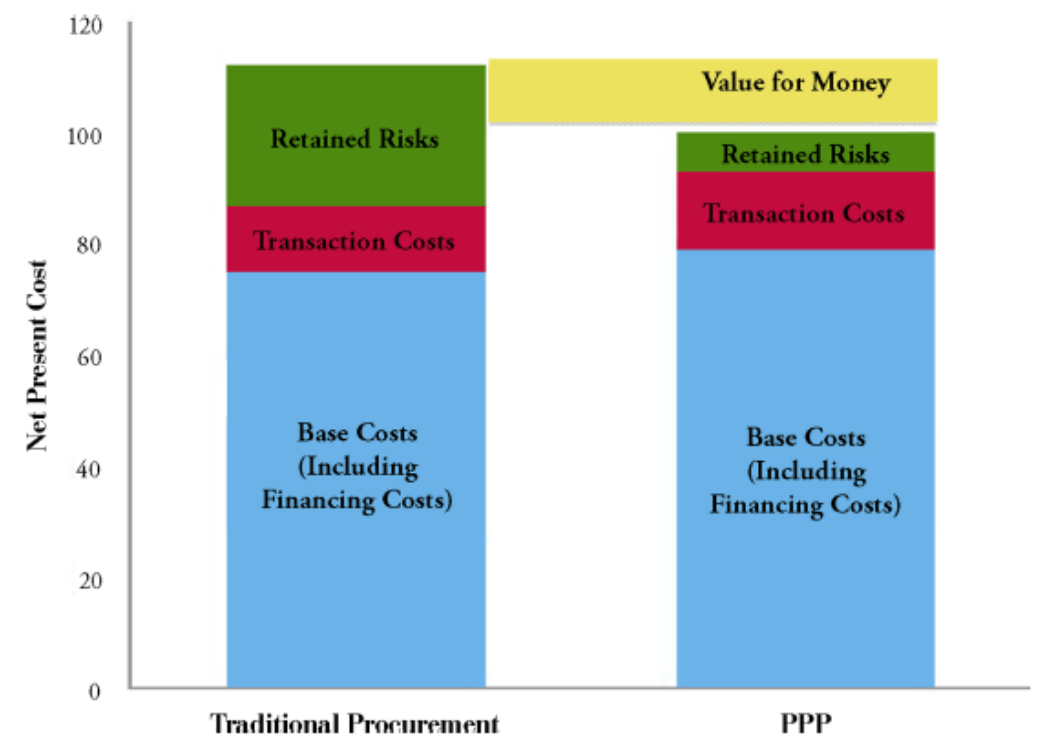

Figure 2. Components of a Value for Money Calculation. Source: Siemiatycki and Farooqi (2012, p. 288).

\subsection{Criticisms Associated with P3s}

Although P3s boast a number of purported benefits in terms of cost savings and risk transfer, some critics suggest that the governance structure of P3 projects presents 
an inherent tension between the public sector and private agency that ultimately hinders attempts at maintaining the public interest. In particular, Vining and Boardman (2008a) note that the public sector and private sector are guided by contradictory principles within a P3 arrangement; the private firm seeks to bolster profits over the course of the contract whereas the public agency looks to reduce short-term expenditures and political costs. This suggests that the private agency will embrace any opportunity throughout the lifespan of the contract to extract additional profit regardless of whether such actions are in the public interest. In a study involving 10 Canadian P3s, the authors argue that the benefits of a P3 are often outweighed by high contract costs and externalities. For example, with the case of the Highway 407 Express Toll Route in Ontario, a weakly designed contract meant that the private sector was able to raise the tolls frequently, which ultimately resulted in public backlash and costly legal proceedings. Eventually the Ontario government was able to reach an agreement with the 407 ETR on toll prices, but only after lengthy court battles. Therefore, while in theory a P3 should be able to tap into the competitive advantage and economic efficiency of the private sector, the inherent tensions between the goals of the private sector and the public sector can often result in higher transaction costs and negative impacts on the public interest.

Further criticisms lodged against P3s are that the introduction of a private sector partner often results in substantial political and democratic costs. As Flyvbjerg, Bruzelius, and Rothengatter (2003: 111) contend: "The role of government is, in principle to represent and protect the public interest... and therefore it must at all times be possible for the public to verify whether this is indeed the case". Therefore, the 
motivation for profit engendered by the private sector often conflicts with the government's mandate to protect the public interest, which often results in trade-offs between transparency and commercial confidentiality. Furthermore, the partnership between public and private creates project complexity that often makes it challenging to trace pertinent project information within the organizational structure of the P3 (Flinders, 2005). Such was the case with the Landsdowne Park redevelopment in Ottawa, where any endeavours to engage with the public were hindered by a lack of access to important documents such as cost and comparative options (Krawchenko and Stoney, 2011). As the introduction of a private entity to infrastructure provision meant the government had to protect proprietary information, they were led to reduce project transparency in order to accommodate private interests. While the extent to which the government is required to maintain confidentiality on certain components of a P3 project is up for debate (Siemiatycki, 2007), secrecy has become a common element across most P3 projects. Therefore, balancing the need for commercial confidentiality while ensuring the integrity of the democratic process and public engagement is an important consideration when planning P3 projects.

Other critics of P3 projects question the extent to which a partnership between the public and private sectors can indeed result in cost savings or VfM for the government. Although VfM is a calculation conducted in the initial project planning stages to determine whether a P3 would deliver cost savings over a traditional procurement approach, there is considerable evidence to suggest that VfM calculations do not in fact represent the economic reality of a project over the course of its lifespan. In actuality, some P3 projects have indeed delivered cost savings whereas others have 
been renegotiated at a considerable expense to tax payers (International Transport Forum, 2013). These contradictory results are corroborated by Hodge and Greve (2007), who also suggest that part of the reason for the inconclusiveness of the results is a lack of data, poor project rigor, and lack of independent evaluators. Siemiatycki (2009) would also add that a lack of ex post evaluations that are conducted several years after project implementation prevents an effective assessment as to whether a project has resulted in public interest benefits over time. Ultimately, the extent to which P3s can deliver VfM is likely a function of the unique project characteristics and planning process rather than whether the project was conducted via a P3 as such. In a review of 72 P3 reports, the National Audit Organization in the UK concluded that "private finance can deliver benefits but is not suitable at any price or in every circumstance" (National Audit Office, 2011, p. 4). Therefore, developing a set of criteria to evaluate P3s must account for individual project characteristics in order to be able to identify from the outset whether or not particular projects are conducive to the P3 delivery model.

Upon reviewing the considerable criticisms presented against P3s, it becomes increasingly evident that most academic critiques do not reject P3s outright, but merely present examples of when P3s have failed. Indeed if there is one common theme permeating the literature on P3s in megaprojects, it is that there is evidence of both successes and failures in the provision of infrastructure through P3s. Consequently, developing an evaluative framework for assessing P3s necessitates understanding the elements that allow projects to succeed while also identifying aspects of a project that 
have contributed to failure. This paper will now take a closer look at attempts within the literature to develop a set of criteria with which to apply to megaprojects.

\subsection{Developing Evaluative Criteria for P3s}

As P3s become increasingly popular as a vehicle for delivering transportation infrastructure, it will become especially important to develop a means for evaluating P3 projects so that a determination can be made whether certain projects are able to maintain the public interest. As van Marrewijk, Clegg, Pitsis, and Veenswijk (2008) note, megaprojects bring together differing and competing partners, interests, values, and modes of rationality under a wide range of contractual arrangements. Therefore, determining whether the public interest is maintained in a P3 necessitates developing an evaluative framework that accounts for the complexity inherent to P3s.

Considerable attention has been given to evaluating P3s over the past decade through such diverse academic lenses as political economy, public administration, economic geography, project management, and urban planning. Using a political economy lens to analyze the adoption and outcome of P3s, Vining and Boardman (2008b: 156-158) distill eight main rules for government geared towards maintaining control over the contract for the public sector:

1. Establish a jurisdictional P3 constitution,

2. Separate the analysis, evaluation, contracting/administrating, and oversight agencies,

3. Ensure that the bidding process is reasonably competitive,

4. Be wary of projects that exhibit high asset-specificity, are complex or involve high uncertainty, and where in-house contract management effectiveness is low, 
5. Include standardized, fast, low-cost arbitration procedures in all P3 contracts,

6. Avoid stand-alone private sector shells with limited equity from the real private sector principals,

7. Prohibit the private-sector contractor from selling the contract too early, and

8. Have a direct conduit to debt holders.

While such rules provide a means for governments to test whether they are ensuring sufficient control throughout the lifespan of a project, they neglect wider "public interest" concern with a P3 such as network connectivity and private-sector innovations and may be overly prescriptive thus hampering their ability to encapsulate the diverse nature of P3 contracts. A more qualitative approach was undertaken by Jacobson \& Choi (2008) who use such measures as open communication and trust, respect, willingness to compromise/collaborate, and other factors to evaluate the success of a P3. While such an evaluative framework recognizes that P3s are imbedded in complex social networks, it is too abstract and subjective to be useful to planners concerned with the "practical" implications P3s present for the public interest. From the project management perspective is the comprehensive set of measures developed by Zhang (2005) who identify nearly 47 subfactors that contribute to a successful P3. Such factors include low environmental impact, public safety and health considerations, low financial charges, limited competition from other projects, and other factors that would be of interest to a project manager. However, such measures are focused almost entirely on the project itself and neglect other public interest considerations such as network connections, public consultation, and transparency. Consequently, there is no one-size-fits-all 
approach to evaluation, and whether or not a particular project is a success partly depends on what perspective one is adopting and what one's role is in the P3 project.

As planners, we often find ourselves at the nexus of diverse perspectives and must often combine different academic lenses in order to discern the public interest from highly-contested, complex infrastructure projects. As such, an evaluative framework from a planning perspective would necessarily encompass economic, social, and political factors. Perhaps the most robust evaluative framework with which to apply to P3 projects from a transportation planning perspective has been advanced by Siemiatycki (2009: 53-54), who outlines a set of nine criteria based on the procedural, spatial design, public policy, and political implications of P3s. It is these nine criteria which inform the research design in the section to follow. 


\section{Research Design}

This paper will take a case study approach to illuminate both the strengths and shortcoming of IO's AFP process in terms of upholding the public interest as illustrated by the Eglinton Crosstown LRT. In order to evaluate the extent to which the Eglinton Crosstown has successfully upheld the public interest, the evaluative criteria established by Siemiatycki (2009) will be used. Although Siemiatycki advanced nine criteria with which to evaluate transportation infrastructure project, this paper will only use seven due to limited access to certain proprietary information and due to the fact that the project has not yet been completed. Consequently, the seven criteria upon which the case study will be evaluated are derived from Siemiatycki (2009, p. 53-54), and are as follows:

1. Did it tap new money for infrastructure?

2. Did it undermine systemwide planning?

3. Did it spur project-level innovation?

4. Did it limit meaningful community consultation and involvement?

5. Were supply and demand risks transferred to the private partners?

6. Do the contract terms constrain future options?

7. Does the PPP deliver value for public money?

Each criterion will be evaluated sequentially based on secondary data sources, with data derived mainly from project documents released by Metrolinx or Infrastructure Ontario, in addition to any other policy or government documents that address the Eglinton Crosstown. A broader discussion on IO's AFP process will conducted through reviewing IO's own literature on P3s and calculating VfM, bolstered by insight gained 
from IO project managers. A set of recommendations on how to maintain the public interest will then be advanced based on the findings from both the Eglinton Crosstown and IO's broader approach to P3s in Ontario. 


\section{Case Study}

\subsection{Public-Private Partnerships in Ontario and Infrastructure Ontario}

Although public-private partnerships are a relatively recent phenomenon in Ontario, they have become an almost paradigmatic means of procuring major infrastructure in the province. The origins of this shift can be traced back to the early 1990s, where the province was grappling with ways to inject innovation and learning into a broader restructuring with the global economy (Wolfe and Gertler, 2001). While both major political parties in Ontario recognized the need for enhanced partnerships with the private sector, their approaches were different. In the early 1990s, the governing New Democratic Party embarked on P3s that were aimed at facilitating collaboration between private firms, unions, and financial agencies in order to advance social goals (Bradford, 2003). However, when the Conservative government came to power in 1995, the new government embraced a different perspective on P3s that involved a more business-like approach to governance geared towards transmitting private sector values and practices in the provision of major infrastructure (Courchene, 1999, as cited in Bradford, 2003). It is this latter approach to P3s that eventually dominated the province's direction on major infrastructure provision in Ontario, thus resulting in the establishment of a special purpose government agency for promoting and managing P3s.

The current provincial government agency mandated with promoting the use of P3s in infrastructure projects in Ontario is Infrastructure Ontario (IO). IO is tasked with "[providing] a wide range of services to support the Ontario government's initiatives to modernize and maximize the value of public infrastructure and realty... in cooperation 
with the private sector." (Infrastructure Ontario, 2016a). Additionally, IO has outlined five key principles with which to guide its operations: transparency, accountability, value for money, public ownership and public control, and public interest. Of particular importance in IOs AFP approach to major infrastructure is its Value for Money (VfM) calculation, which is conducted throughout the procurement process to assess the extent to which a P3 will achieve greater value for a project over the traditional delivery model (Infrastructure Ontario, 2015a). If after conducting the VfM calculation for a project it is determined that a P3 would deliver cost savings to the public sector then a P3 would be pursued for that project.

To date, IO has been involved with numerous infrastructure projects both as a project manager and an advisor. While the bulk of projects have been focused on the provision of public buildings such as health centres, hospitals, and courthouses, a few transportation projects have been undertaken through the AFP model. In general, most transportation projects are either still under construction or are currently receiving proposals from private consortia (Infrastructure Ontario, 2016b). Of particular interest for the purposes of this project is the Eglinton Crosstown LRT in Toronto. This project is important from a planning perspective as it represents a key pieces of transit infrastructure that requires a huge investment of public time and resources. The success of this project will play a key role in proving the effectiveness of P3s in the provision of major transit infrastructure and garnering support for IO's AFP model in the future. 


\subsection{Eglinton Crosstown LRT}

\section{Background}

The Eglinton Crosstown LRT is a light rail transit line currently under construction in Toronto that will play a prominent role as an East-West connection in the region's transit system. Its $19 \mathrm{~km}$ length will run along the Eglinton Avenue corridor between Mount Dennis and Kennedy Station and will include 25 stations and stops and link to local bus routes, subways stations, and a range of GO Transit lines (Infrastructure Ontario, 2016c). Between Kelle Street and Lair Drive, the Eglinton Crosstown will go underground for a length of 10km (see Appendix). In 2011, Metrolinx began the boring work required for the underground portions of the new transit line (Kalinowski, 2011).

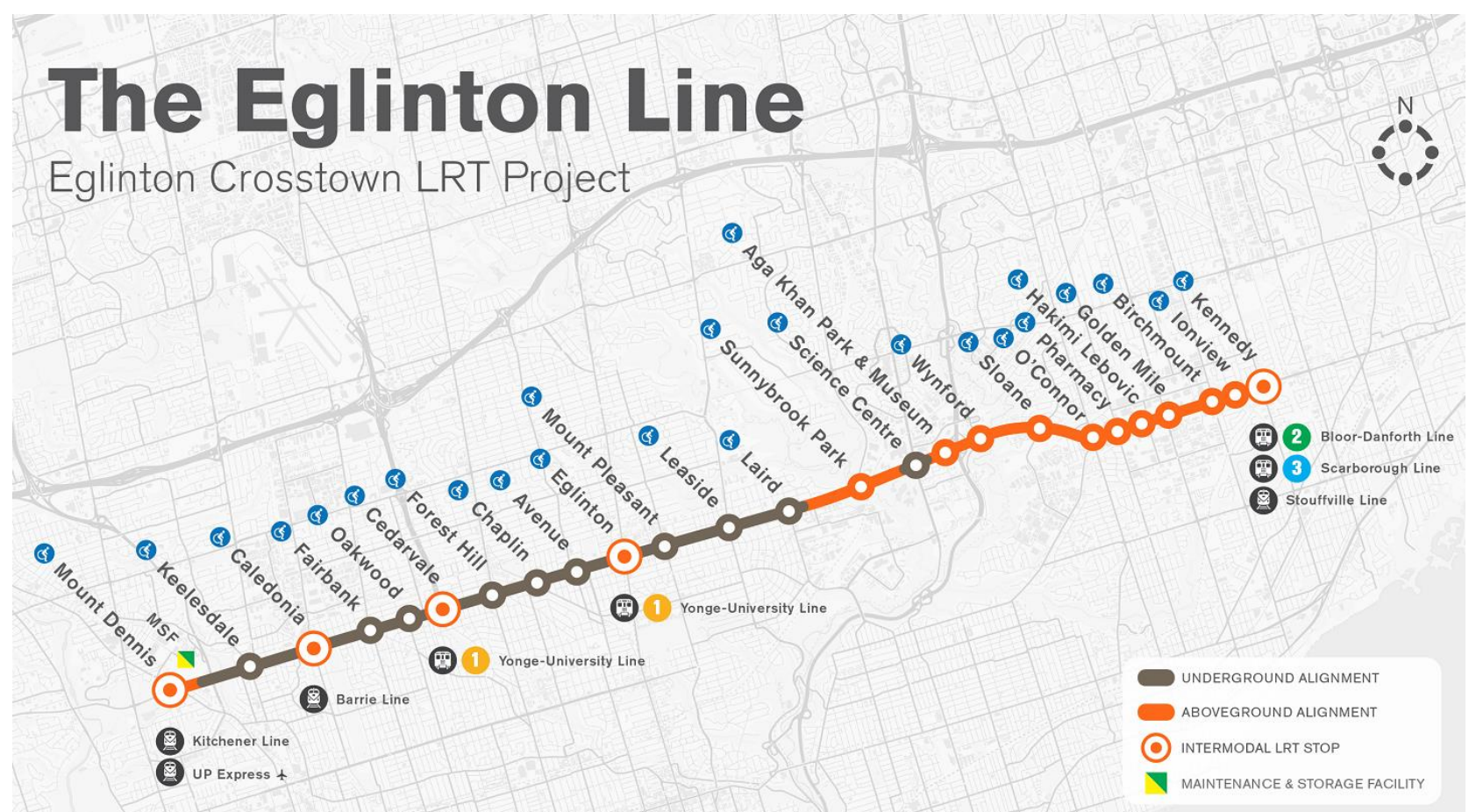

Figure 3. The Eglinton Crosstown LRT Route. Source: Metrolinx, 2016. 


\section{Did it tap new money for infrastructure?}

While early construction was ongoing, Infrastructure Ontario initiated the AFP process in order to assess the suitability of the project for a P3 and solicit bids from the public sector. After an RFP process of approximately 16 months, the contract for the Eglinton Crosstown was awarded to Crosslinx Transit Solutions on July $24^{\text {th }}, 2015$, with a planned construction period from 2015-2021. As a Design-Build-Finance-Maintain (DBFM) contract, the private consortium is responsible for nearly every aspect of the project except for operating the trains. Crosslinx is responsible for lifecycle maintenance of the LRT system and its components (stations, track work, mechanical systems, etc.) for a 30 year period. Both the construction and maintenance of the Eglinton Crosstown and its various facilities are subject to minimum quality and performance standards as outlined in the project agreement (Infrastructure Ontario, 2015b). Upon expiry of the 30 year maintenance contract, the private consortium will turn the project over to the Province "in good working order within specific prescribed standards" (Infrastructure Ontario, 2016c, p. 11). In addition, the terms of the contract stipulate that Crosslinx is responsible for financing the capital cost for construction of the Eglinton Crosstown (Infrastructure Ontario, 2015b). Any cost-underestimation, delays, or other events that require additional financing will be the responsibility of the private consortium.

\section{Did it undermine system-wide planning?}

The Eglinton Crosstown has emerged from a planning context that recognizes the need for greater provision of public transit in the GTHA, especially in facilitating East-West connections. The particular corridor along Eglinton Avenue between Pearson and Scarborough Town Centre has been identified by the regional transit agency, 
Metrolinx, as a top priority. According to Metrolinx's (2008) regional transportation plan, The Big Move, rapid transit along Eglinton Avenue was envisioned for full implementation within 15 years. Not only does the Eglinton Crosstown fulfill a major component of the regional transportation plan, its scheduled final completion date of March $28^{\text {th }}, 2022$, fits within the 15 year goal established by The Big Move (Infrastructure Ontario, 2015b).

Although it is still early in the construction phase, it appears that the initial plans and designs for the Eglinton Crosstown's transit line and stations are upholding the parameters established by Toronto's Official Plan and an Eglinton-specific planning study. Eglinton Avenue is identified as an "Avenue" in Toronto's Official Plan, which means that intensification is encouraged and improvements should be made to enhance transit service and the pedestrian environment (City of Toronto, 2015). Furthermore, with the vision of the Official Plan in mind, the City of Toronto embarked on a significant two year consultation for the Eglinton Corridor involving over 60 public and stakeholder consultations. The culmination of this extensive public consultation process was the Eglinton Connects planning study which provided more specific design recommendations on the public realm, building massing and achieving transit-oriented development within the context of a new LRT (City of Toronto, 2014a). The Eglinton Connects planning study resulted in 21 recommendations which were adopted by council, including recommendations that LRT station sites encouraged mixed-use development, enhance the public realm, and facilitate connections to existing paths and trails for active transportation (City of Toronto, 2014b). A review of each of the stations reveals that stations generally facilitate transfers to existing transit and active 
transportation routes, present opportunities for mixed-use development, and contain plazas and other public realm improvements (Metrolinx, 2016). Consequently, the planning and design associated with stations along the Eglinton Crosstown route uphold regional, city-wide, and local plans.

\section{Does the P3 deliver VfM?}

Although the Eglinton Crosstown is still under construction thus making it impossible to conduct a complete ex post $\mathrm{VfM}$ calculation, a considerable amount of VfM has been conducted both before and after the signing of the P3 contract. As per its standard VfM methodology, IO conducted a VfM analysis through three stages of the procurement process: prior to the release of the Request for Proposals (RFP), during the assessment of bids in the RFP process, and upon financial close when the project agreement was finalized (Infrastructure Ontario, 2015a). The final VfM was made publically available and will now be reviewed to determine the extent to which IO has applied a rigorous process to establishing a public benefit case for the AFP model for the Eglinton Crosstown on account of cost savings.

The extent of cost savings IO projected on account of its VfM calculation suggests that the AFP model would deliver substantial savings over the traditional procurement method. As Figure 3 shows, $1 \mathrm{O}$ conducted a VfM analysis based on base project costs (financing, design, construction, lifecycle, and maintenance), AFP ancillary costs (transaction and legal costs), and retained risks (potential for adverse events that may impact the project) (Infrastructure Ontario, 2016c). Although the traditional project was associated with lower transactional and base costs due to more competitive borrowing rates, lower legal expenditures, and lower lifecycle costs, these savings were 
overshadowed by the substantial risk reduction achieved through private sector involvement. Consequently, IO determined that the AFP model for the Eglinton Crosstown would deliver a savings of 2.18 billion or $22 \%$ percent over a traditional public sector project.

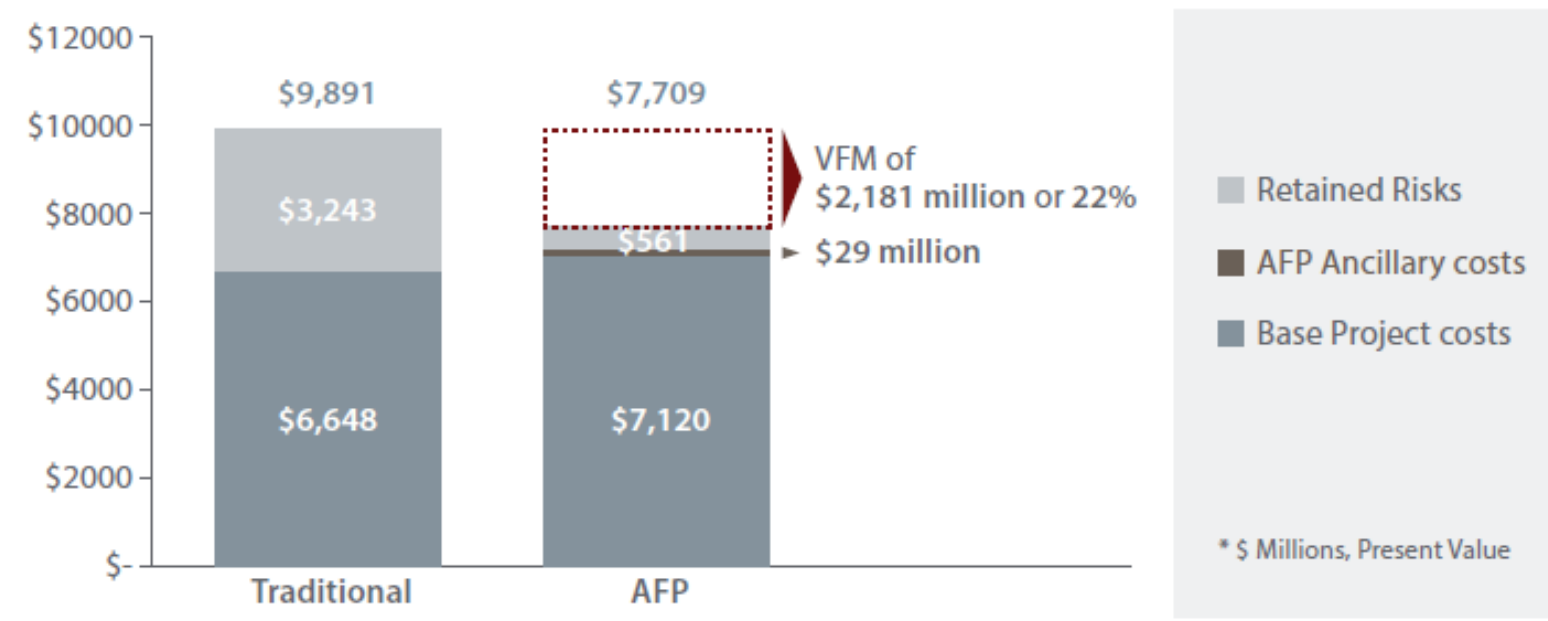

Figure 4. Value for Money Calculation for Eglinton Crosstown. Source: Infrastructure Ontario (2016c, p. 2)

Did it limit meaningful community consultation and involvement?

As a project that has been on the public radar since at least the release of the Transit City Plan in 2007, the Eglinton Crosstown has been the recipient of considerable scrutiny and public consultation for the past 8 years. Initial public consultation for the project can be traced back to 2008, when the Toronto Transit Commission conducted four public consultation stages based on preliminary design and planning considerations for the proposed LRT. As Table 2 shows, 28 open houses and community meetings were conducted between August 2008 and February 2010 involving at least 3188 participants. After collecting all the data from the stakeholder feedback and public consultations, the TTC then compiled a list of 34 key elements which were then addressed with actionable steps or relevant responses. Consequently, it is clear from 
the TTCs responses from the consultation in the early planning stages of the Eglinton Crosstown that public feedback would be addressed in a systematic way. In many cases, feedback synthesized in this way resulted in new studies being carried out, or new components being introduced in the plans (Toronto Transit Commission, 2010).

\begin{tabular}{|c|c|c|c|}
\hline Event & Number of Events & Number of Participants & Date(s) \\
\hline \multicolumn{4}{|l|}{ Formal Open Houses } \\
\hline First Round of Public Open Houses & 6 & 691 & August - September 2008 \\
\hline Second Round of Open Houses & 6 & 1004 & June - July 2009 \\
\hline Third Round Open House & 1 & 139 & September 2009 \\
\hline Fourth Round of Open Houses & 7 & 860 & November - December 2009 \\
\hline Total & 20 & 2694 & August - December 2009 \\
\hline \multicolumn{4}{|l|}{ Community Meetings } \\
\hline Mount Dennis Community Meeting & 1 & 75 & December 14th, 2009 \\
\hline Ward 34 Open House & 1 & 144 & January 14th, 2010 \\
\hline Airport Corporate Centre Businesses & 1 & 3 & January 18th, 2010 \\
\hline $\begin{array}{l}\text { Mount Dennis Community Association } \\
\text { Meeting }\end{array}$ & 1 & 2 & January 28th, 2010 \\
\hline $\begin{array}{l}\text { Latvian Canadian Cultural Centre } \\
\text { Board Meeting }\end{array}$ & 1 & not specified & February 1st, 2010 \\
\hline Ward 4 Public Meeting & 1 & 120 & February 3rd, 2010 \\
\hline Ward 34 Meeting & 1 & not specified & February 9th, 2010 \\
\hline Ward 11 and Ward 12 Community & 1 & 150 & February 11th, 2010 \\
\hline Total Community Meetings & 8 & 494 & December 2009 - February 2010 \\
\hline Total Open Houses and Community & 28 & 3188 & August 2008 - February 2010 \\
\hline
\end{tabular}

Table 2. Public Consultation Events for the Eglinton Crosstown, 2008-2010. Data compiled from Toronto Transit Commission (2010).

According to IO's project documents, consultation has been incorporated in nearly every stage of the project. The Eglinton Connects planning study was the culmination of two years of stakeholder consultation and studies, resulting in a number of recommendations on improvements to the public realm, surrounding development patterns, transportation connectivity, and urban design (City of Toronto, 2014b). Not only do such consultations incorporate resident feedback, they offer opportunities for resident to offer feedback on how the Eglinton Crosstown fits in with surrounding land 
uses and the trajectory of development along the corridor. Other opportunities for feedback have included open houses on station design and naming, in addition to regular updates on traffic conditions and road closure throughout construction (Metrolinx, 2016). In terms of public consultation, the Eglinton Crosstown has been the recipient of considerable feedback from local residents, project stakeholders, and the general public throughout every stage of the process, thus suggesting that the P3 model has not limited opportunities for public consultation in this case.

\section{Were supply and demand risks transferred to the private partners?}

The contract for the Eglinton Crosstown presents a unique risk allocation structure that tends to distribute construction risk to the private sector and demand risk to the public sector. According to the VfM document for the project, Crosslinx is entirely responsible for designing, building, financing, and maintaining the LRT for 30 years, with the Province specifically stating that "any extra costs incurred as a result of a schedule overrun caused by the contract will not be paid by the Province" (Infrastructure Ontario, 2016c, p. 11). A closer look at the project agreement reveals that construction risk is indeed transferred to the Crosslinx, with accommodations only made due to actions taken by the province or employees that may unduly delay the project (such as a strike) or due to acts of nature or force majeure (Infrastructure Ontario, 2015b). With Crosslinx responsible for costs associated with the construction of the Eglinton Crosstown, the public sector is effectively insulated from the risk associated with cost overruns and construction delays.

As a DBFM contract, demand risk is borne by the public sector since Crosslinx is not tasked with operating or collecting fares for the actual operations of the LRT. 
Consequently, if Metrolinx has overestimated traffic volumes than any shortfalls in revenue will be dealt with solely by the public sector. Therefore, in the case of the Eglinton Crosstown, none of the demand risk has been transferred to the private firm.

\section{Did it spur project-level innovation?}

Achieving project level innovation is one of the key drivers of the P3 model and as such it is important to evaluate the extent to which partnering with the private sector has spurred innovation for the Eglinton Crosstown. While specific details on project innovation are not typically disclosed to the public due to proprietary reasons, there are a few aspects of innovation that Crosslinx has brought to the project.

In broad terms, perhaps the biggest innovation presented through the P3 model for the Eglinton Crosstown has been the bundling of design, construction, and maintenance. In particular, the bundling of these components has allowed Crosslinx to carefully consider design aspects for each of the stations in order to maintain a high quality experience for customers and lower life-cycle costs over time (Metrolinx and Infrastructure Ontario, 2015). Since Crosslinx is tasked with maintaining the facilities, it has been in its best interest to use higher quality and more durable materials in the construction phase in order to reduce maintenance costs later on. With output specifications built into Schedule 16 of the project agreement (Infrastructure Ontario, 2015b), Crosslinx is also required to achieve minimum requirement in maintenance and rehabilitation in order to maintain a high quality experience for transit users and ensure that the asset is transferred to the public sector in good condition upon expiry of the 30 year contract. Therefore, the unique bundling of services under the P3 contract has encouraged Crosslinx to implement innovations that achieve quality and cost-savings 
over the lifespan of the transit line while still allowing $I O$ to specify quality standards to ensure a positive customer experience.

A more specific example of project innovation initiated by Crosslinx was the inclusion of a back-up power element to the Eglinton Maintenance and Storage Facility. Recognizing that the company was tasked with maintaining the transit line, Crosslinx developed a back-up source of power for an event such as a system failure or power outage. (Metrolinx \& Infrastructure Ontario, 2015). Not only does such a facility better allow the company to adhere to its maintenance requirements in terms of reducing down-time, it provides for more efficient energy usage and lower lifecycle energy costs. Once again, the bundling of design, construction, and maintenance encouraged the private firm to look at a project holistically and consider ways to enhance efficiency and reduce costs over the lifespan of the project.

While the aforementioned examples present some important ways that the Eglinton Crosstown has achieved project innovation through an enhanced role for the private sector throughout the project, it is important to recognize that Crosslinx was not tasked with boring the tunnels for the transit line. Consequently, any innovation associated with bundling the boring of tunnels with the rest of the construction would not be encouraged through the current formulation of the contract. However, it should be noted that innovation is not the only concern associated with the boring of tunnels. As a capital intensive and lengthy process, the public sector initiated tunneling for Eglinton in 2012, which may have allowed the transit line to be completed earlier than expected and reduced the complexity of the contract through the AFP model. 


\section{Do the contract terms constrain future options?}

Since the Eglinton Crosstown is a DBFM contract, the contract inherently offers a greater degree of flexibility for the public sector to plan future projects. This is because the private firm is not earning revenue from transit fares, and is thus unaffected by any future decisions the public sector may have in constructing competing lines that may draw ridership away from the Eglinton Crosstown. As demand risk is solely borne by Metrolinx in recouping costs through transit fares, the private sector does not have any interest in preventing the construction of future transit lines or other transportation infrastructure. 


\section{Discussion}

The case study has shown how IO tackles major transportation infrastructure projects through its AFP approach, with a particular emphasis on its procurement process, management approach, and public engagement methods for one project. The seven criteria were applied to the Eglinton Crosstown to evaluate the extent to which the forthcoming LRT line maintains the public interest. This paper will now discuss the implications of the findings regarding $\mathrm{IO}$ and the Eglinton Crosstown, with a particular emphasis on recommendations to enhance the procurement of major transportation projects through P3s in the future.

An assessment as to how effectively the AFP process for the Eglinton Crosstown adheres to the seven criteria reveals that IO has indeed incorporated public interest concerns in its approach to the P3s. As results from the case study show, the Eglinton Crosstown has effectively addressed most of the public interest concerns, especially in terms of public engagement and adhering to existing plans. While one may claim that IO may have missed an opportunity for further project innovation by not bundling the boring of tunnels in the AFP contract, one must also consider that the Eglinton Crosstown is a priority transit line in the region, and that work on the project needed to begin concurrently with the AFP process if Metrolinx was to meet its 15 year goal for project completion.

Contrary to the findings of Krawchenko and Stoney (2011) the use of a P3 for the Eglinton Crosstown does not seem to have resulted in an opaque planning process. The public consultation process for the Eglinton Crosstown has not been any less transparent than traditional projects, and it appears both IO and Metrolinx have been 
receptive to public concerns and incorporated public feedback into the planning process. Furthermore, the amount of data available to the public is especially high, with the VfM calculation, the project agreement, the results from public consultations, and numerous other documents available openly to the public on the Eglinton Crosstown project website. Although the amount of data $\mathrm{IO}$ has released on the project has considerably enhanced transparency, some sections of the project agreement such as the quality standards and penalties for failing maintenance audits were redacted. While it should be acknowledged that some components of the project agreement should remain confidential for proprietary reasons, it is not immediately clear why those sections in particular were hidden from the public, as they directly tie into public interest concerns over high quality infrastructure and a positive customer experience. This finding corroborates Siemiatycki's (2007) finding that certain information on P3s is often withheld from the public without a clear explanation or reason.

Although there has been some support for allocating demand risk (i.e. ridership potential) to the private sector (Page, Ankner, Jones, \& Fetterman, 2008), such a structure may not have been ideal for the Eglinton Crosstown, and may have in fact constrained the public sector's ability to plan for future infrastructure. As Siemiatycki and Friedman (2012) suggest, transferring demand risk may not be ideal in every case, and that transit projects in particular may be at risk of legal disputes later on if ridership does not meet projections or competing infrastructure gets built. In the case of the Eglinton Crosstown, avoiding the transfer of demand risk to the private sector gives the public sector a less constrained ability to plan future infrastructure without fear of impinging on the private firm's ability to capture revenue generated from users. This allows Crosslinx 
to focus on design and construction efficiencies, without creating an overly complex contract that may have become problematic in the future.

However, despite the many successes exemplified by the Eglinton Crosstown in upholding the public interest, one must be careful not to generalize about IO's approach based on one example. Indeed, a review of IO other transportation infrastructure projects suggest that the level of transparency embodied by the Eglinton Crosstown's is not shared by all IO projects. For instance, getting the same information from the ION LRT line in Waterloo, such as the project agreement, the VfM calculation, and the results of public consultations is currently not possible, despite construction also being well underway (Infrastructure Ontario, 2016d). Therefore, in order to be able to make broader comparisons about the AFP process across projects and aggregate findings from research, a similar level of consistency and transparency needs to be incorporated across all projects.

Finally, while $\mathrm{IO}$ is generally good at calculating VfM consistently across projects and only selecting projects which can be justified based on a better return-oninvestment for the public, informal discussions with IO staff revealed there is currently no uniform ex post evaluation conducted at a predesignated time after substantial project completion. 10 recognizes the need to conduct ex post evaluations upon project completion, especially in light of the Auditor General's (2014) report. However, there is no structured ex post evaluation incorporated into project agreements or IO's AFP process. The organization currently does such evaluations in response to events (such as the Auditor General's report), or in an ad hoc manner. Having such a component embedded in the organization's AFP process can allow for better research into the 
success of P3s in transportation infrastructure, and result in the development of "lessons learned" based on comparable evaluations between projects. 


\section{Conclusion and Recommendations}

The case study of the Eglinton Crosstown LRT highlights the considerable advancements the Province of Ontario has made in addressing the early criticisms presented against the use of P3s for major transportation infrastructure. Existing literature has often claimed that the P3 model is frequently in conflict with the public interest, citing concerns over a lack of transparency, a lack of consultation, loss of public control, and financially costly contracts. And while these concerns certainly have strong empirical support from existing case studies on P3s (Vining and Boardman, 2008a; Flinders, 2005; Krawchenko and Stoney, 2011; Siemiatycki, 2007), Ontario's current AFP approach addresses many of these early concerns and attempts to better incorporate the public interest in the procurement, management, and implementation of P3s in the province. As the Eglinton case study shows, IO has been able to successfully incorporate seven criteria pertaining to the public interest in the AFP process for the Eglinton Crosstown.

Despite the many positive attributes embodied by the Eglinton Crosstown in terms of achieving VfM, incorporating public consultation, and effectively transferring risk, there is still room for IO to improve its AFP model as a whole. In particular, there is a need to consistently address the public interest in transportation projects by more systematically incorporating the seven criteria in the AFP process for all P3 projects. The following recommendations are presented to better incorporate the public interest in future transportation projects procured through IO's AFP model:

- Establish more uniform reporting standards upon which each project should adhere. Documents published for each project should be similar in order to 
allow comparisons between project and encourage greater transparency for the AFP process. For example, a VfM calculation should be available for each project in order to compare or aggregate projects in terms of the value for money they are purported to achieve.

- When omitting certain information from the publically-accessible project agreement due to legal reasons or otherwise, a justification should be provided for that omission (i.e. commercial confidentiality, sensitive information etc.). If the omission of such materials cannot be justified on legal of privacy grounds then that material should be released to the public to offer a more transparent account of the project.

- Establish a timeline for the publication of ex post VfM evaluations for transportation infrastructure projects. Ex post $\mathrm{VfM}$ evaluations conducted after substantial project completion are crucial in order to determine whether initial VfM calculations were correct and whether the public interest was maintained in other aspects of a project. By establishing a timeline for the publication of such reports, projects can more easily be compared and $\mathrm{IO}$ will be forced to maintain a consistent schedule in evaluating its projects.

By incorporating the above recommendations in the AFP model, it is hoped that IO can establish a more rigorous method for evaluating completed P3 projects while more consistently incorporating public interest concerns in the development of major transportation infrastructure projects in the future.

With so much at stake in the provision of major transportation infrastructure, it is crucial that all public sector agencies in Ontario are equipped with the right information 
and tools to make informed decisions on selecting appropriate projects for the P3 model. As planners, it is especially important for us to champion the inclusions of spatial, social, and democratic components when evaluating P3s so that government can make informed decisions on how best to promote the public interest when soliciting the private sector for greater involvement in transportation projects. But while developing and applying an effective evaluative framework is an important component in upholding the public interest in major infrastructure projects, it falls short of offering concrete ways to enhance the P3 arrangement in operational terms so that both the public and private agencies can optimize the outcome of a particular project. Future research could be directed at evaluating specific components of the P3 process to determine which project management processes and methods can contribute to a successful project. 


\section{References}

Bradford, N. (2003). Public-private partnership? Shifting paradigms of economic governance in Ontario. Canadian Journal of Political Science, 36(5), 1005-1033.

Campbell, H. (2012). 'Planning ethics' and rediscovering the idea of planning. Planning Theory, 11(4), 379-399.

City of Toronto. (2014a). Eglinton Connects: City of Toronto Planning Study, Executive Summary. Retrieved from http://www1.toronto.ca/City\%200f\%20Toronto/ City\%20Planning/Urban\%20Design/Eglinton\%20Connects/Apri14\%20Update/Eg Connects\%20ExecSum\%20Final.pdf.

City of Toronto. (2014b). Eglinton Connects planning study - Final directions report [City Council Decision, PG32.4]. Retrieved from http://app.toronto.ca/tmmis/ viewAgendaltemHistory.do?item=2014.PG32.4.

City of Toronto. (2015). City of Toronto: Official Plan. Retrieved from http://www1.toronto.ca/planning/chapters1-5.pdf.

Courchene, T. (1999). Responding to the NAFTA challenge: Ontario as a North American region state and Toronto as a Global City. Paper presented at Global City-Regions Conference, Los Angeles, October 21-23.

De Bettignies, J. \& Ross, T. (2004). The economics of public-private partnerships. Canadian Public Policy, 30(2), 135-154.

Flinders, M. (2005). The politics of public-private partnerships. British Journal of Politics and International Relations, 7(2), 215-239.

Flyvbjerg, B. (2007). Policy and planning for large-infrastructure projects: Problems, causes, cures. Environment and Planning B: Planning and Design, 34(4), 578- 
597.

Flyvbjerg, B., Bruzelius, N, \& Rothengatter, W. (2003). Megaprojects and risk: An anatomy of ambition. Cambridge: Cambridge University Press.

Flyvbjerg, B, Holm, M. \& Buhl, S. (2003). What causes cost overrun in transport infrastructure projects? Transport Reviews, 24(1), 3-18.

Grant, J. (2005). Rethinking the public interest in planning. Plan Canada, 45(2), 48-50.

Grimsey, D. \& Lewis, M. (2002). Evaluating the risks of public private partnerships for infrastructure projects. International Journal of Project Management, 20(2), 107118.

Grimsey, D. \& Lewis, M. (2005). Are public private partnerships value for money? Evaluating alternative approaches and comparing academic and practitioner views. Accounting Forum, 29, 345-378.

HM Treasury. (2006). Value for Money Assessment Guidance. London: Her Majesty.

Hodge, G. \& Greve, C. (2007). Public-private partnerships: An international performance review. Public Administration Review, 67(3), 545-558.

Infrastructure Canada. (2007). Infrastructure and productivity: a literature review. [Ebook]. Retrieved from Ryerson University Library Catalogue.

Infrastructure Ontario. (2015a). Assessing value for money: An updated guide to Infrastructure Ontario's Methodology - March 2015. Retrieved from http://www.infrastructureontario.ca/Templates/Projects.aspx?id=2147488710\&lan gtype $=1033$.

Infrastructure Ontario. (2015b). Project agreement, execution version: Eglinton Crosstown LRT Project. Retrieved from http://www.infrastructureontario.ca/ 
Templates/Project.aspx id=2147491907\&mode=1\&langtype=1033 .

Infrastructure Ontario. (2016a). About Infastructure Ontario. Retrieved from

http://www.infrastructureontario.ca/templates/AboutUsWithCarousel.aspx?ID=12 0\&langtype $=1033$.

Infrastructure Ontario. (2016b). AFP Projects. Retrieved from http://www.infrastructureontario.ca/Templates/Projects.aspx?id=2147488309\&lan gtype $=1033$.

Infrastructure Ontario. (2016c). Value for money assessment: Eglinton Crosstown Light Rail Transit. Retrieved from http://www.infrastructureontario.ca/Templates/ Project.asp $\mathrm{P}$ id $=2147491907 \&$ mode $=1$ \&langtype $=1033$.

Infrastructure Ontario. (2016d). Region of Waterloo's light rail transit system. Retrieved from http://www.infrastructureontario.ca/Templates/Projects.aspx? $i d=2147492247$ \&langtype $=1033$.

International Transport Forum (2013), Better Regulation of Public-Private Partnerships for Transport Infrastructure, ITF Round Tables, No. 151. Paris: OECD Publishing. Jacobson, C. \& Choi, S. (2008). Success factors: Public works and public-private partnerships. International Journal of Public Sector Management, 21(6), 637-657. Kalinowski, T. (2011). Metrolinx order tunnelling machines. Toronto Star. Retrieved from http://www.thestar.com.

Kawk, Y., Chih, Y., \& Ibbs, C. (2009). Towards a comprehensive understanding of public private partnerships for infrastructure development. California Management Review, 51(2), 51-60.

Koppenjan, J. (2008). Public-private partnership and mega-projects. In H. Priemus, B. 
Flyvbjerg, \& B van Wee (Eds.). Decision-making on mega-projects: Cost-benefit analysis, planning and innovation. (pp. 189-212). Northampton, MA: Edward Elgar Publishing.

Krawchenko, T. \& Stoney, C. (2011). Public private partnerships and the public interest: A case study of Ottawa's Lansdowne Park Development. Canadian Journal of Nonprofit and Social Economy Research, 2(2), 74-90.

van Marrewijk, A., Clegg, S., Pitsis, T., \& Veenswijk, M. (2008). Managing public-private megaprojects: Paradoxes, complexity, and project design. International Journal of Project Management, 26(6), 591-600.

Metrolinx. (2008). The big move: Transforming transportation in the Greater Toronto and Hamilton Area. Retrieved from http://www.metrolinx.com/thebigmove/ Docs/big_move/TheBigMove_020109.pdf.

Metrolinx. (2016). Eglinton Crosstown. Retrieved from http://www.thecrosstown.ca/. Metrolinx and Infrastructure Ontario. (2015). Eglinton Crosstown LRT: Innovating for value and efficiency. Retrieved from http://www.infrastructureontario.ca/ Templates/ Project.aspx?id=2147491907\&mode=1 \&langtype=1033.

Morallos, D. \& Amekudzi, A. (2008). The state of the practice of value for money: Analysis in comparing public private partnerships to traditional procurements. Public Works Management \& Policy, 13(2), 114-125.

National Audit Office. (2011). Lessons from PFI and other projects. Report by the Comptroller and Auditor General. London, England: The Stationery Office. Office of the Auditor General of Ontario. (2014). Infrastructure Ontario - Alternative Financing and Procurement. 2014 Annual Report of the Office of the Auditor 
General of Ontario. (193-217). http://www.auditor.on.ca/en/reports_en/en14/ 305en14.pdf.

Ortiz, I. \& Buxbaum, J. (2008). Protecting the public interest in long-term concession agreements for transportation infrastructure. Public Works Management \& Policy, 13(2), 126-137.

Page, S., Ankner, W., Jones, C., \& Fetterman, R. (2008). The risks and rewards of private equity in infrastructure. Public Works Management \& Policy, 13(2), 100113.

Province of Ontario. (2014a). Ontario population projections. Ministry of Finance. Retrieved from http://www.fin.gov.on.ca/en/economy/demographics/ projections/\#s2.

Province of Ontario. (2014b) 2014 Ontario Economic Outlook and Fiscal Review Chapter 1: Building Opportunity, Securing our Future. Ministry of Finance. Retrieved from http://www.fin.gov.on.ca/en/budget/fallstatement/2014/ chapter1c.html.

Rietveld, P. (1989). Infrastructure and regional development: A survey of multiregional economic models. The Annals of Regional Science, 23(4), 255-274.

Sanchez-Robles, B. (1998). Infrastructure investment and growth: Some empirical evidence. Contemporary Economic Policy, 16(1), 98-108.

Siemiatycki, M. (2007). What's the secret? Confidentiality in planning infrastructure using public/private partnerships. Journal of the American Planning Association, 73(4), 388-403.

Siemiatycki, M. (2009). Delivering transportation infrastructure through public-private 
partnerships: Planning concerns. Journal of the American Planning Association, 76(1), 43-58.

Siemiatycki, M. \& Farooqi, N. (2012). Value for money and risk in public-private partnerships. Journal of the American Planning Association, 78(3), 286-299.

Siemiatycki, M \& Friedman, J. (2012). The trade-offs of transferring demand risk on urban transit public-private partnerships. Public Works Management \& Policy, 17(3), 283-302.

The Canadian Council for Public-Private Partnerships. (2015). Why choose PPP's? Retrieved from http://www.pppcouncil.ca/resources/about-ppp/why-chooseppp.html.

Toronto Transit Commission. (2010). Chapter 6: Consultation process. In Eglinton Crosstown Light Rail Transit: Transit Project Assessment. (pp. 305-323). Retrieved from http://thecrosstown.ca/sites/default/files/pdf/reports/CrosstownLRT-Environmental-Project-Report/chapter-6-consultation-process.pdf.

Vining, A. \& Boardman, A. (2008a). Public-private partnerships in Canada: Theory and evidence. Canadian Public Administration, 51(1), 9-44.

Vining, A., \& Boardman, A. (2008b). Public-private partnerships: Eight rules for government. Public Works Management \& Policy, 13(2), 149-161.

Wolfe, D. \& Gertler, M. (2001). Globalization and economic restructuring in Ontario: From industrial heartland to learning region? European Planning Studies, 9(5), $575-592$.

Yescombe, E. (2007). Public-private partnerships: Principles of policy and finance. Burlington, MA: Elsevier. 
Zhang, X. (2005). Critical success factors for public-private partnerships in infrastructure development. Journal of Construction Engineering and Management, 131(1), 314. 